\title{
Programmed death of leukocytes through Fas and TNFR1 in malnourished patients with pancreatic
}

\section{cancer}

\section{Programowana śmierć leukocytów indukowana przez receptory śmierci Fas i TNFR1 u niedożywionych chorych $\mathrm{z}$ rakiem trzustki}

\author{
Sylwia Kędziora ${ }^{1}$, Robert Słotwiński ${ }^{12}$, Waldemar L Olszewski², Marzanna Zaleska², Gustaw Lech ${ }^{3}$, \\ Maciej Słodkowski ${ }^{3}$, Ireneusz W. Krasnodębski ${ }^{3}$ \\ 1Department of Immunology and Nutrition, Medical University of Warsaw, Poland \\ 2Department of Surgical Research and Transplantology, Medical Research Center, Polish Academy of Sciences, Poland \\ ${ }^{3}$ Department of General, Gastroenterological and Oncological Surgery, Medical University of Warsaw, Poland
}

Przegląd Gastroenterologiczny 2011; 6 (1): 30-35 DOI: 10.5114/pg.2011.20105

Key words: pancreatic cancer, apoptosis, immune dysfunction.

Słowa kluczowe: rak trzustki, apoptoza, zaburzenia układu odpornościowego.

Address for correspondence: Sylwia Kędziora, MSc, Department of Immunology and Nutrition, Medical University of Warsaw, Pawińskiego 3, 02-106 Warszawa, tel. +48 225720 247, fax +48 225720 246, e-mail: sylwia.kedziora@wum.edu.pl

\begin{abstract}
Aim: To evaluate the status of programmed leukocyte death (apoptosis) in malnourished pancreatic cancer patients in comparison with healthy controls.

Material and methods: The percentage of leukocytes with death receptors Fas (CD95) and TNFR1 (CD120a) was investigated in 72 pancreatic cancer patients in comparison with 30 healthy volunteers. Percentages of cells with receptors were assessed by flow cytometry.

Results: Results of the study show a significantly higher percentage of CD95+/CD3- cells and lymphocytes with TNFR1 in the group with pancreatic cancer in comparison with healthy controls.

Conclusions: Our studies show up-regulation of the pro-apoptotic signalling system in the leukocytes of patients with pancreatic cancer and a switch to apoptosis. These alterations may lead to leukocyte dysfunction and immune system suppression.
\end{abstract}

\section{Introduction}

Mortality associated with pancreaticoduodenectomy has decreased dramatically to less than $5 \%$ over the past 2 decades in high-volume centres, but persistent high morbidity rates have remained an important concern for patients, healthcare providers, and payers [1-6]. While mortality is an objective and easily quantifiable outcome parameter, morbidity is only poorly defined, and this

\section{Streszczenie}

Cel: Ocena programowanej śmierci leukocytów (apoptozy) u niedożywionych chorych z rakiem trzustki w porównaniu z grupą zdrowych ochotników.

Materiat i metody: $U 72$ chorych z rakiem trzustki za pomocą cytometrii przepływowej badano odsetek leukocytów z receptorami śmierci Fas (CD95) i TNFR1. Grupę kontrolną stanowiło 30 zdrowych ochotników.

Wyniki: U chorych z rakiem trzustki w porównaniu z grupą kontrolną stwierdzono istotnie podwyższony odsetek komórek CD95+/CD3- oraz istotnie podwyższony odsetek limfocytów z receptorem TNFR1 na powierzchni.

Wnioski: Badania wskazują na zwiększoną aktywność proapoptotycznych szlaków sygnałowych i możliwość wzmożonej śmierci leukocytów u chorych z rakiem trzustki. Zmiany te mogą prowadzić do zaburzeń funkcjonowania leukocytów i immunosupresji układu odpornościowego.

shortcoming has severely hampered conclusive comparisons among centres and within the same institution over time [7-9]. One reason for this high morbidity is immunosuppression in pancreatic cancer [10-12], which contributes to postoperative complications. One process which is especially important for proper functioning of the immune system is apoptosis of immune cells such as leukocytes. Apoptosis or programmed cell death is a cen- 
tral regulator of tissue homeostasis, which causes elimination of redundant, damaged or infected cells. Apoptosis is critical in the formation of organs, limbs and other body structures, and in maintaining the function of most of the systems in an adult body. Therefore, dysregulation of the apoptotic signalling processes often leads to serious consequences, such as neurodegenerative diseases, cancer or autoimmunity [13-16]. One pathway of leukocyte apoptosis is the extrinsic pathway through death receptors such as Fas and TNFR1 (fig. 1). These receptors bind intracellular adapter molecules (TRADD and FADD), which recruit pro-caspase 8 , create the death-inducing signalling complex (DISC) and activate caspase 8. Then caspase 8 activates caspase 3 , leading to degradation of key intracellular substrates [17].

To evaluate the status of immune cell apoptosis, we investigated expression of death receptors Fas (CD95) and TNFR1 (CD120a) in peripheral blood leukocytes of pancreatic cancer patients in comparison with healthy controls.

\section{Material and methods Patients}

Eighty-eight patients with pancreatic cancer were admitted to the study. According to the criteria of investigation 16 patients were excluded (patients over 75 , patients with metastasis, patients with unresectable tumours, patients treated with chemo- or radiotherapy or immunosuppressors, and those suffering from chronic liver or kidney diseases and diabetes). Seventy-two patients (mean age $62.1 \pm 8.9$ ) were classified according to UICC (TNM classification of malignant tumours) $[18,19]-3$ patients were classified as stage I, 44 patients were at stage $\mathrm{II}$, and 25 patients were at stage III. After full clinical diagnostic procedures (imaging and laboratory tests) all patients were subjected to pancreatic head resection (Whipple's pancreaticoduodenectomy). A histopathological examination confirmed the diagnosis.

Nutritional status (loss of body mass, body mass index [BMI], albumin concentration and total lymphocyte count) was assessed. According to the ESPEN (The European Society for Clinical Nutrition and Metabolism) definition of malnutrition [20] our study included 5 patients (6.9\%) with slight malnutrition ( $<5 \%$ weight loss within 2 months), 43 patients (59.7\%) with moderate malnutrition (5-10\% weight loss within 3 months) and 24 patients (33.3\%) with severe malnutrition ( $>10 \%$ weight loss within 6 months). The characteristics of nutritional status of patients are shown in table I.

The control group comprised 30 healthy sex- and age-matched volunteers.

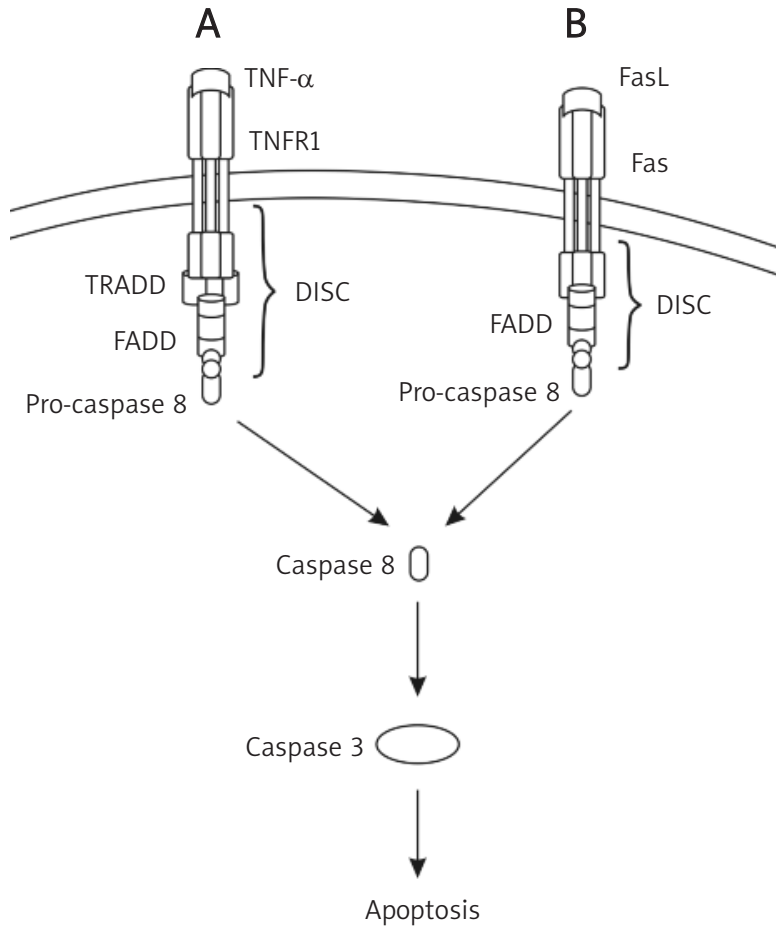

Fig. 1. Schematic diagram of extrinsic pathway of apoptosis. (A) Binding of TNF- $\alpha$ to receptor TNFR1 allows binding of the intracellular adapter molecules TRADD and FADD and recruitment of pro-caspase 8 leading to formation of the complex DISC. Activation of caspase 8 and activation of caspase 3 initiate apoptosis. (B) Binding of FasL to receptor Fas allows binding of the intracellular adapter molecule FADD and recruitment of pro-caspase 8 leading to formation of the complex DISC. Activation of caspase 8 and activation of caspase 3 initiate apoptosis TNF- $\alpha$ - tumour necrosis factor, TNFR1 - TNF receptor-1, Fas CD95, FasL - CD95L, Fas ligand, TRADD - TNFR-associated death domain, FADD - Fas-associated protein with death domain, DISC - death-inducing signalling complex

Ryc. 1. Schemat zewnętrznego szlaku apoptozy. (A) Przyłaczenie TNF- $\alpha$ do receptora TNFR1 pozwala na przyłaczenie biatek adaptorowych TRADD i FADD oraz prokaspazy 8 i utworzenie kompleksu DISC. Aktywacja kaspazy 8 prowadzi do aktywacji kaspazy 3 i inicjuje apoptozę. (B) Przyłaczenie Fas $L$ do receptora Fas pozwala na przyłączenie biatka adaptorowego FADD oraz prokaspazy 8 i utworzenie kompleksu DISC. Aktywacja kaspazy 8 prowadzi do aktywacji kaspazy 3 i inicjuje apoptoze

TNF- $\alpha$ - czynnik martwicy nowotworu, TNFR1 - receptor-1 TNF- $\alpha$, Fas - CD95, FasL - CD95L, ligand receptora Fas, TRADD - biatko adaptorowe $z$ domena śmierci (DD) wiażace się z receptorem TNFR1, FADD - biatko adaptorowe z domena śmierci (DD) wiażace się z receptorem Fas, DISC - kompleks sygnalny indukujący śmierć 
Table I. Nutritional status of patients

Tabela I. Stan odżywienia chorych

\begin{tabular}{lc} 
Parameters & Results \\
\hline Weight loss [\%] & $10.49 \pm 5.37$ \\
\hline Albumin [d/dl] & $3.22 \pm 0.49$ \\
\hline Total lymphocyte count [cells $\left./ \mathrm{mm}^{3}\right]$ & $1354 \pm 288$ \\
\hline BMI $\left[\mathrm{kg} / \mathrm{m}^{2}\right]$ & $24.8 \pm 4.6$
\end{tabular}

\section{Flow cytometry}

The peripheral blood of each patient was collected for flow cytometry analyses. For staining of surface proteins, $100 \mu \mathrm{l}$ heparinised blood samples were incubated with $20 \mu \mathrm{l}$ of the following monoclonal antibodies: CD3 PE, CD95 FITC (Becton Dickinson Biosciences) and CD120a PE (Beckman Culter) and their appropriate isotype-matched control antibodies. After $30 \mathrm{~min}$ of incubation at room temperature, red cells were lysed by the addition of FACS Lysing Solution (Becton Dickinson Biosciences) to the tubes. After another 10 minutes, samples were washed in PBS with $1 \%$ bovine serum azide $\left(\mathrm{NaN}_{3}\right)$ and fixed with $1 \%$ paraformaldehyde (Sigma, Chemical Co).

The stained cells were acquired using the LSR instrument (Becton Dickinson) to detect two fluorescence parameters and two scatter parameters. The data were analysed using Cell Quest Pro Software, version 9.2 (Becton Dickinson) and expressed as the percentage of lymphocytes with positive surface protein expressions (means $\pm \mathrm{SD}$ ).

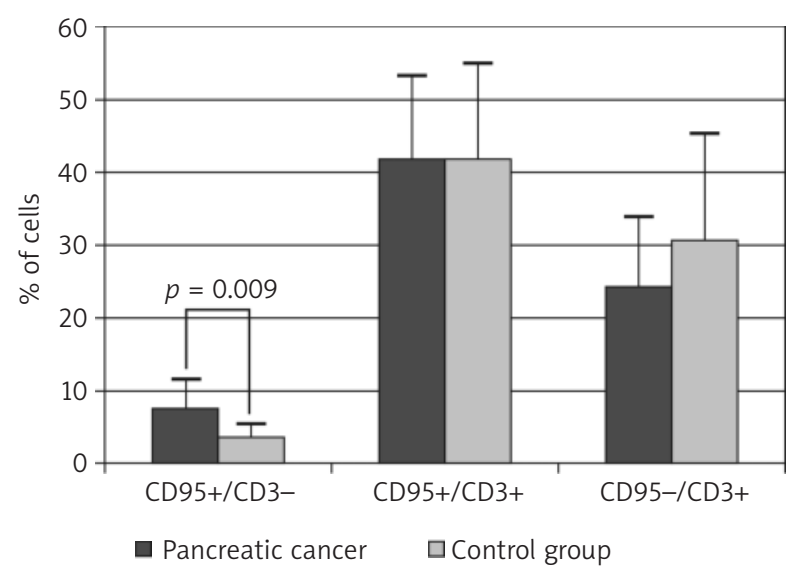

Fig. 2. Percentage of leukocytes with receptor Fas (CD95) in pancreatic cancer patients in comparison with healthy controls

Ryc. 2. Odsetek leukocytów z receptorem Fas (CD95) u chorych z rakiem trzustki w porównaniu z grupą kontrolna

\section{Statistics}

Statistical analysis was performed using the StatSoft Statistica v.7.0 program. To evaluate the statistical significance of the difference in percentage of cells with death receptors between the group with pancreatic cancer and the control group Mann-Whitney test with Bonferroni correction was used. Significance was set at $p<0.05$.

\section{Results}

The percentage of some leukocytes with receptors involved in programmed lymphocyte death is altered in pancreatic cancer patients as compared to healthy controls. The percentage of CD95+/CD3- cells was significantly higher in pancreatic cancer patients as compared to the healthy control group ( $p=0.009$ ) (fig. 2, 4a). On the other hand, the percentage of CD95-/CD3+ cells was lower in pancreatic cancer patients as compared to the healthy control group, but there was no significance.

The percentage of lymphocytes, monocytes and granulocytes with receptor TNFR1 (CD120a) was higher in pancreatic cancer patients as compared to the healthy control group. However, there were significant differences only for lymphocytes with TNFR1 between the pancreatic cancer group and the control group (fig. 3, 4b).

\section{Discussion}

Our results show significantly higher expression of Fas (CD95) on CD3- cells and TNFR1 (CD120a) on lymphocytes in patients with pancreatic cancer as compared to healthy controls, which corresponds to the overexpression of pro-apoptotic proteins on leukocytes. These alterations revealed up-regulation of the proapoptotic signalling system in the leukocytes of patients with pancreatic cancer and switch to apoptosis.

While apoptosis is an essential biological process for normal development and maintenance of tissue homeostasis, it is also involved in a number of pathological conditions including tissue injury, degenerative diseases, immune diseases and cancer [21]. Whether activated by membrane-bound death receptors [22] or by stress-induced mitochondrial perturbation with subsequent cytochrome c release [23], the activation of downstream caspases leads to stepwise cellular destruction by disrupting the cytoskeleton, shutting down DNA replication and repair, degrading chromosomal DNA and finally disintegrating the cell into apoptotic bodies [24]. Several mechanisms of activation of apoptosis in different physiological or pathological conditions in cells have been proposed and studied intensively [25]. Numerous factors, especially death receptors Fas (CD95) and TNFR1 (CD120a), have been suggested to play an essential role in the apoptotic process. 
The extrinsic pathway of apoptosis can be induced through members of the TNF/TNFR superfamily such as receptor 1 for TNF- $\alpha$ (TNFR1/CD120a) and receptor Fas (CD95). The receptors and ligands in this superfamily have unique structural attributes that couple them directly to signalling pathways for cell proliferation, survival, and differentiation. Thus, they have assumed prominent roles in the generation of tissues and transient microenvironments. Most TNF/TNFR are expressed in the immune system, where their rapid and potent signalling capabilities are crucial in coordinating the proliferation and protective functions of pathogen-reactive cells [26]. Receptors TNFR1 and Fas take part in the initial stage of apoptosis, which is a reversible phase. Only the execution process (connected with execution caspases, cytoplasmic endonuclease, cytoplasmic proteases, degradation of nuclear and cytoskeletal proteins) is irreversible and definitely indicates cell death [27].

Our findings demonstrate high expression of TNFR1 in the lymphocytes of patients with pancreatic cancer, which may suggest an increased level of apoptosis of peripheral blood lymphocytes in patients with pancreatic cancer by the extrinsic pathway. Other studies have shown a high level of TNFR1 in the lymphocytes of patients after heart transplants [28] and HIV infected patients [29]. Also in patients with head and neck cancer the peripheral blood mononuclear cells had a significantly higher proportion of apoptotic cells than these cells of controls. The authors suggest that activated TNFR1+ and also Fas+ cells are pre-programmed to die [30].

Our data also demonstrate high expression of CD95+ in the CD3- cells of patients with pancreatic cancer, which may also suggest an increased level of programmed death in these cells. Other studies have shown decreased expression of Fas (CD95) on peripheral blood lymphocytes but increased Fas (CD95) expression on tumour-infiltrating lymphocytes in patients with renal cell carcinoma in comparison with healthy volunteers [31]. However, other studies suggest that peripheral blood mononuclear cells of kidney transplant recipients are more susceptible to activation-induced cell death and that the Fas-FasL pathways is involved in this process [32]. Similar results were obtained in patients with non-small cell lung cancer. The proportion of blood CD95+ lymphocytes was significantly higher when compared with healthy people. Moreover, this proportion was higher in smokers when compared with non-smokers [33]. Enhanced expression of Fas receptor on lymphocytes was also observed in gastric mucosa in children during Helicobacter pylori infection [34].

Our results show overexpression of death receptors on leukocytes in patients with pancreatic cancer as compared with healthy controls. These alterations

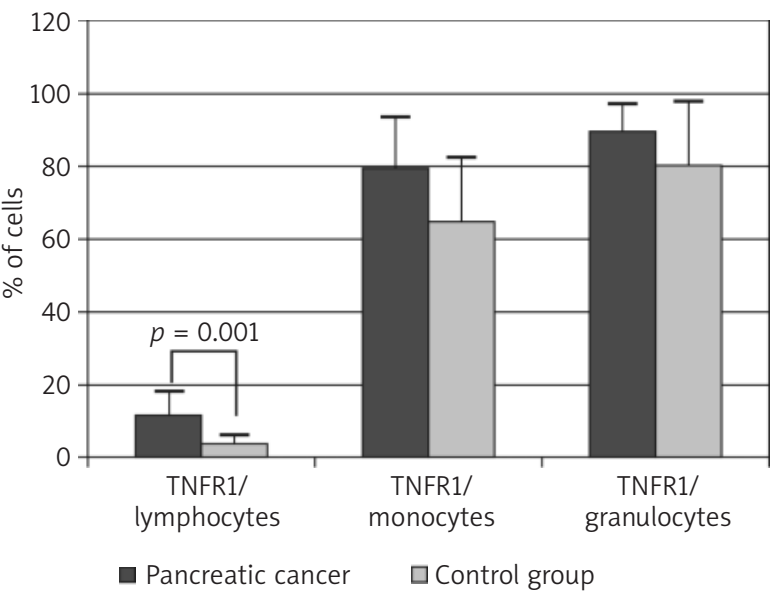

Fig. 3. Percentage of leukocytes with receptor TNFR1 (CD120a) in pancreatic cancer patients in comparison with healthy controls

Ryc. 3. Odsetek leukocytów z receptorem TNFR1 (CD120a) u chorych z rakiem trzustki w porównaniu z grupa kontrolna

revealed up-regulation of the pro-apoptotic signalling system in the leukocytes of patients with pancreatic cancer and the possibility to switch to apoptosis. This suggests that patients with pancreatic cancer may show an increased level of leukocyte dysfunction and consequently higher immune system suppression. This can further lead to a greater number of infectious complications, organ failure and a higher death rate, especially after pancreatic resection [35-38]. A possible explanation of inappropriate changes in expression of death receptors on leukocytes in patients with pancreatic cancer is that these patients are mostly malnourished. The frequency of malnutrition in patients with pancreatic cancer ranges from $80 \%$ to $85 \%$ [39]. This is malnutrition which, apart from reduced skeletal, cardiac and respiratory muscle function, poor wound healing and loss of non-fat body mass, causes impairment of immune functions as a response to under-nutrition of immune cells [40]. To improve the nutritional status of immune cells it may be required to introduce pre-operative immuneenhancing diets as a routine procedure after flow cytometry examination. It may lead to some changes in the expression of apoptotic proteins and perhaps a decrease or even elimination of the differences in the expression of these proteins between patients with pancreatic cancer and healthy people.

In conclusion, our studies show up-regulation of the pro-apoptotic signalling system in the leukocytes, mainly lymphocytes, of patients with pancreatic cancer and a possibility to switch to apoptosis as compared with healthy people. These alterations may lead to leukocyte dysfunction and immune system suppression. This prob- 
A CD95/CD3

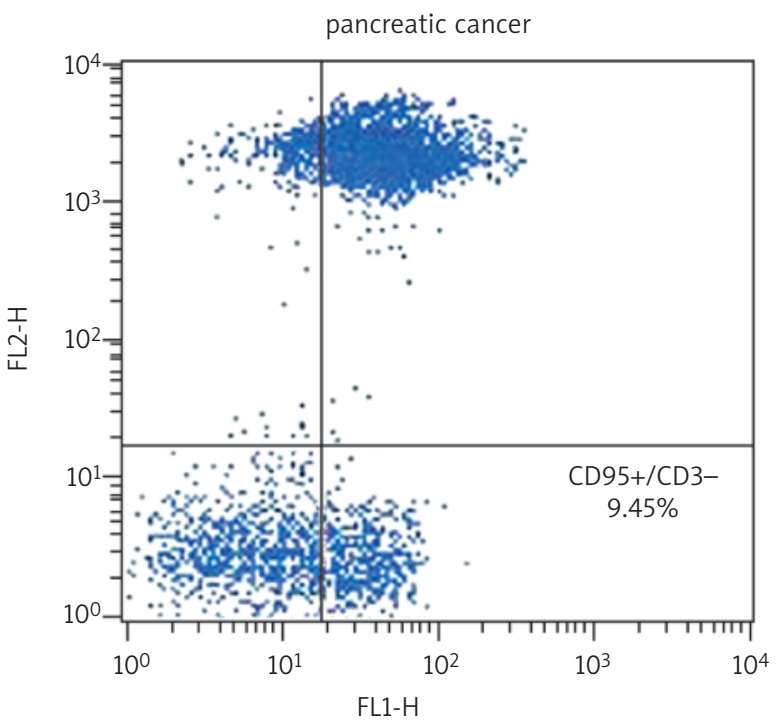

B CD120a (TNFR1)/lymphocytes

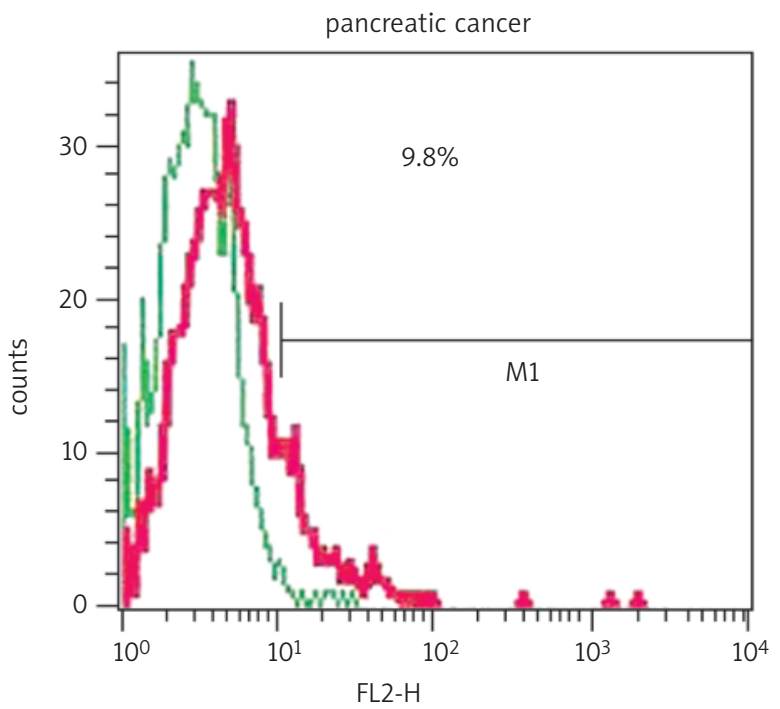

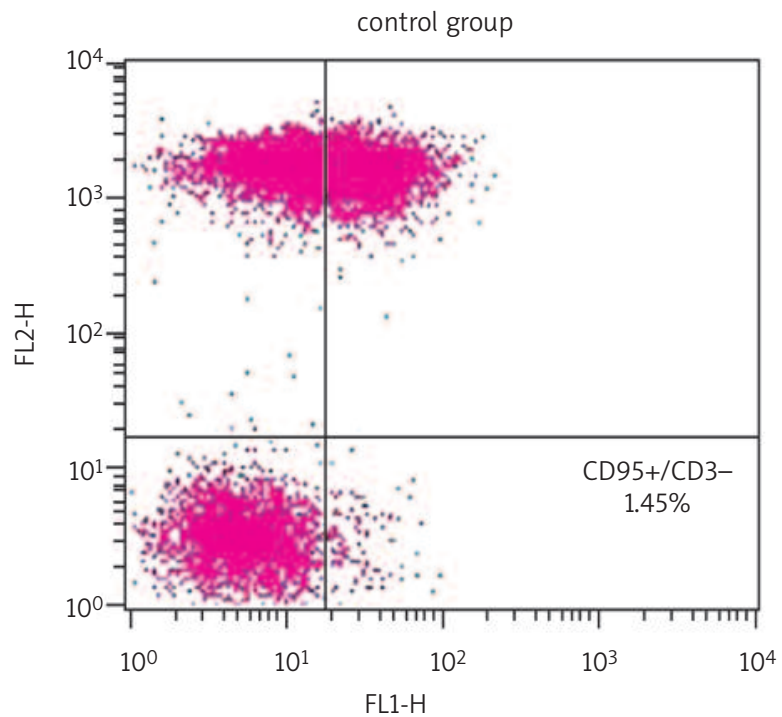

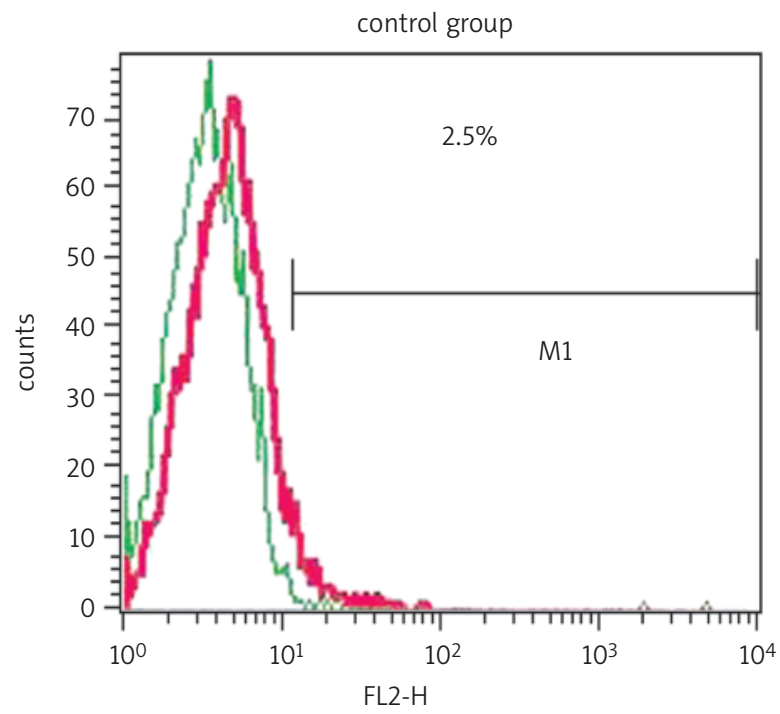

Fig. 4. Selected charts/histograms of flow cytometry. (A) Percentage of CD3 cells with CD95 (Fas) receptor,

(B) percentage of lymphocytes with CD120a (TNFR1) receptor

Ryc. 4. Wybrane histogramy z cytometrii przepływowej. (A) Odsetek komórek CD3 z receptorem CD95 (Fas),

(B) odsetek limfocytów z receptorem CD120a (TNFR1)

lem can be resolved by introducing pre-operative immune-enhancing diets in patients with pancreatic cancer as a routine procedure after immunological examination. Further research needs to be undertaken to examine this issue.

\section{Acknowledgements}

This work was supported by Projects No. 2 PO5B 05928 and N N402 306836 funded by the Ministry of Science and Higher Education.

\section{References}

1. Yeo CJ, Cameron JL, Sohn TA, et al. Six hundred fifty consecutive pancreaticoduodenectomies in the 1990s: pathology, complications, and outcomes. Ann Surg 1997; 226: 248-57.

2. Bentrem DJ, Yeh JJ, Brennan MF, et al. Predictors of intensive care unit admission and related outcome for patients after pancreaticoduodenectomy. J Gasrointest Surg 2005; 9: 1307-12.

3. Fong $\mathrm{Y}$, Gonen $\mathrm{M}$, Rubin $\mathrm{D}$, et al. Long-term survival is superior after resection for cancer in high-volume centers. Ann Surg 2005; 242: 540-4. 
4. Ho V, Heslin MJ. Effect of hospital volume and experience on inhospital mortality for pancreaticoduodenectomy. Ann Surg 2003; 237: 509-14.

5. Sosa JA, Bowman HM, Gordon TA, et al. Importance of hospital volume in the overall management of pancreatic cancer. Ann Surg 1998; 228: 429-38.

6. Gouma DJ, van Geenen RC, van Gulik TM, et al. Rates of complications and death after pancreaticoduodenectomy: risk factors and the impact of hospital volume. Ann Surg 2000; 232: 786-95.

7. Clavien PA, Sanabria JR, Strasberg SM. Proposed classification of complications of surgery with examples of utility in cholecystectomy. Surgery 1992; 11: 518-26.

8. Clavien PA, Camargo CA Jr, Croxford R, et al. Definition and classification of negative outcomes in solid organ transplantation: application in liver transplantation. Ann Surg 1994; 220: 109-20.

9. Clavien PA, Sanabria JR, Mentha G, et al. Recent results of elective open cholecystectomy in a North American and a European center: comparison of complications and risk factors. Ann Surg 1992; 216: 618-26.

10. von Bernstorff W, Voss M, Freichel S, et al. Systemic and local immunosuppression in pancreatic cancer patients. Clin Cancer Res 2001; 7: 925-32.

11. Poch B, Lotspeich E, Ramadani M, et al. Systemic immune dysfunction in pancreatic cancer patients. Lang Arch Surg 2007; 392: 353-8.

12. Greco E, Fogar P, Mazzon C, et al. Pancreatic cancer pulls down lymphocyte migration. JOP 2007; 8: 685-6.

13. Igney $\mathrm{FH}, \mathrm{Krammer} \mathrm{PH}$. Death and anti-death: tumourresistance to apoptosis. Nature Rev Cancer 2002; 2: 277-88.

14. Ekshyyan O, Aw TY. Apoptosis: a key in neurodegenerative disorders. Curr Neurovasc Res 2004; 1: 355-71.

15. Vermeulen K, van Bocksteale DR, Berneman ZN. Apoptosis: mechanisms and relevance in cancer. Ann Hematol 2005; 84: 627-39.

16. Mahoney JA, Rosen A. Apoptosis and autoimmunity. Curr Opin Immunol 2005; 17: 581-8.

17. Xu G, Shi Y. Apoptosis signaling pathways and lymphocyte homeostasis. Cell Research 2007; 17: 759-71.

18. Wittekind Ch, Sobin LH. TNM classification of malignant tumors. Wiley-Liss, New York 2000.

19. Kulke MH, Anthony LB, Bushnell DL, et al. NANETS Treatment Guidelines: Well-Differentiated Neuroendocrine Tumors of the Stomach and Pancreas. Pancreas 2010; 39: 735-752.

20. Kondrup J, Allison SP, Elia M, et al. Guidelines for Nutrition Screening 2002. Clin Nutr 2003; 22: 415-21.

21. Lowe SW, Lin AW. Apoptosis in cancer. Carcinogenesis 2000; 21: 485-95.

22. Walczak H, Krammer PH. The CD95 (APO-1/Fas) and the TRAIL (APO-2L) apoptosis systems. Experimental Cell Res 2000; 256: 58-66.

23. Loeffler $M$, Kroemer $G$. The mitochondrion in cell death control: certainties and incognita. Experimental Cell Res 2000; 256: 19-26.

24. Nagata S. Apoptotic DNA fragmentation. Experimental Cell Res 2000; 256: 12-8.

25. Vaux DL, Korsmeyer SJ. Cell death in development. Cell 1999; 96: 245-54.
26. Locksley RM, Killeen N, Lenardo MJ, et al. The TNF and TNF receptor superfamilies: integrating mammalian biology. Cell 2001; 104: 487-501.

27. Elmore S. Apoptosis: a review of programmed cell death. Toxicol Pathol 2007; 35: 495-516.

28. Ankersmit HJ, Moser B, Zuckermann A, et al. Activation-induced $T$ cell death, and aberrant $T$ cell activation via TNFR1 and CD95-CD95 ligand pathway in stable cardiac transplant recipients. Clin Exp Immunol 2002; 128: 175-80.

29. de Oliveira Pinto LM, Garcia S, Lecoeur H, et al. Increased sensitivity of $\mathrm{T}$ lymphocytes to tumor necrosis factor receptor 1 (TNFR1) and TNFR2-mediated apoptosis in HIV infection: relation to expression of $\mathrm{Bcl}-2$ and active caspase- 8 and caspase3. Blood 2002; 99: 1666-75.

30. Saito T, Kuss I, Dworacki G, et al. Spontaneous ex vivo apoptosis of peripheral blood mononuclear cells in patients with head and neck cancer. Adv Brief 1999; 5: 1263-73.

31. Cardi G, Heaney JA, Schned AR, et al. Expression of Fas(Apo$1 / C D 95)$ in tumor-infiltrating and peripheral blood lymphocytes in patients with renal cell carcinoma. Cancer Res 1998; 58: 2078-80.

32. Carpio VN, Auino-Dias EC, Prochnow TA, et al. Evaluation of apoptosis in peripheral blood lymphocytes of renal transplant patients. Transplant Proc 2006; 38: 1898-900.

33. Hoser G, Wasilewska D, Domagała-Kulawik J. Expression of Fas receptor on peripheral blond lymphocytes from patients with non-small cell lung cancer. Folia Histochemica et Cytobiologica 2004; 42: 249-52.

34. Kotłowska-Kmieć A, Bąkowska A, Szarszewski A, et al. Helicobacter pylori increases expression of proapoptotic markers Fas and FasL on CD4 lymphocytes in children. Acta Biochemica Polonica 2009; 56: 433-8.

35. Poch B, Lotspeich E, Ramadani M, et al. Systemic immune dysfunction in pancreatic cancer patients. Langerbecks Arch Surg 2007; 392: 353-8.

36. Angele MK, Chaudry IH. Surgical trauma and immunosuppression: pathophysiology and potential immunomodulatory approaches. Langebecks Arch Surg 2005; 390: 333-41.

37. Meakins JL. Host defense mechanisms in surgical patients: effect of surgery and trauma. Acta Chir Scand 1998; 550: 43-53.

38. Koerner P, Westerholt A, Kessler W, et al. Surgical trauma and postoperative immunosuppression. Chirurg 2008; 79: 290-4.

39. von Meyenfeldt M. Cancer-associated malnutrition: an introduction. Europ J Oncol Nursing 2005; 9: S35-8.

40. Ziegler TR, Evans ME, Fernandez-Estivariz C, Jones DP. Trophic and cytoprotective nutrition for intestinal adaptation, mucosal repair, and barrier function. Annu Rev Nut 2003; 23: 229-61. 